\title{
The Tragic/Comic Calisto: Obsessed and Insecure
}

\author{
Connie L. Scarborough \\ Texas Tech University
}

To the memory of Alan D. Deyermond

The first mention of Calisto in Celestina ${ }^{1}$ is in the Argumento de toda la obra. Here he is described as "de noble linage, de claro ingenio, de gentil disposición, de linda criança dotado de muchas gracias, de stado mediano" (82). ${ }^{2}$ From the beginning, this description should not be taken at face value. It does not appear in the Comedia de Calisto y Melibea published in Burgos in 1499 edition. The description first appears in the Comedia of 1500 along with the verses written by Proaza at the end of this edition. It is likely not the work of Rojas himself but rather that of his first editor or, perhaps, the anonymous author of the first act. Since it probably reflects Proaza's reading of Calisto, it is up to us, as subsequent readers, to concur, or not, with these evaluations of the male protagonist. Is the Calisto that emerges from the pages of Celestina the Calisto presented in the Argumento? Is he the quintessential parody of the courtly lover as defined by June Hall Martin and others? ? $^{3}$ Is he the eternal adolescent as Maria Rosa Lida de Malkiel argues? Is he a man true to his promises but ultimately misguided by those in whom he places trust? Or is he a total reprehensible egotist? Is he the mujeriego par excellence who, for the time frame of the Tragicomedia, set his sights on Melibea? Or is he, as Castells argues, «a creative and complex personality who... lives in an unstable nighttime

1.- Use of the title, Celestina, is synonymous in this paper with the Tragicomedia de Calisto y Melibea.

2.- All quotes are from Dorothy S. Severin's edition of La Celestina 3rd ed. (Madrid: Cátedra, 1989).

3.- Other critics who have studied Calisto as a parody of the courtly lover include Lacarra, Deyermond and Severin. 
world controlled by his dreams and fantasies» («Calisto and the Imputed Parody of Courtly Love in Celestina» 219). I contend that Calisto, at various times, embodies a little of all these characterizations, and others, as we follow his trajectory throughout the events of the Tragicomedia.

Jerry Rank's comments on Calisto seem especially relevant to this investigation. Rank states: "In many ways, precisely because his character leads itself so readily to stereotyping, Calisto's is one of the most difficult to decipher and he is, I would even propose, one of the most 'subtle' of all the characters of Celestina...» (162). Further complicating an appraisal of Calisto is a fact pointed out decades ago by Peter Dunn. Dunn notes that we only see Calisto, in the Tragicomedia, in the throes of passion and we have no indicators of what he is like when not in this state (112). To arrive at an understanding of Calisto, our only clues are his words, actions and interactions with other characters in the work. This is all that the anonymous author of Act I, or Rojas, wants us to know of him. We must also acknowledge that any "reading of Calisto» has been affected by prior investigators' evaluations of him. Castells notes that "several generations of Hispanists have interpreted Calisto from a number of different perspectives, [and] the many contradictions that exist in contemporary criticism reveal that modern scholars have not yet resolved the inconsistencies that the galán manifests throughout the work" (Fernando de Rojas and Renaissance Vision 81). But perhaps these inconsistencies and contradictions are exactly the stuff of which the Calisto of the Tragicomedia is made. Hence, the subtlety of his character as identified by Rank.

In the encounter between Calisto and Melibea at the beginning of the Tragicomedia (as we know it today), Calisto attributes their meeting to the sacrifices, service, devotion and pious works that he has offered to God. He says that heaven has rewarded him by placing him in a situation where he can speak in private with Melibea. This is where the work of the author of Act I begins and we have no way of knowing if Calisto had performed such acts of religious zealousness in hopes of finding himself alone with Melibea. What we do know is that he knows Melibea by name and she also knows who Calisto is. Baltanás speculates that this initial meeting between the two "hay que suponer un tiempo de cortejo a distancia - miradas, insinuaciones...- por parte de Calisto hasta que un día encuentra el pretexto o la ocasión para hablarle cara a cara y a solas tras el extravío - ¿real? ¿fingid ?- del azor» (5-6). ${ }^{4}$ Most notable in this first scene is that Melibea initially encourages Calisto to express his «secreto dolor» by responding to his proclamation: "En esto veo, Melibea, la grandeza de Dios» (85). In the prologue to their edition of Celestina, Lobera et al. note that, in this encounter, Calisto speaks of his inequality

4.- Deyermond had also supposed a previous and unsuccessful courting of Melibea by Calisto (see his article "Divisiones socio-económicas, nexos sexuales: la sociedad de Celestina»). 
with Melibea, not in terms of social status, but in terms of the unfathomable distance separating a mere mortal from God. They note that the expression of desire in religious terminology is not unprecedented in medieval literature, especially in sentimental fiction and the poetry of the cancioneros (clxv-clxvi). June Hall Martin, who insists that Calisto is a parody of the courtly lover, asserts that «From his first words ... Calisto has insulted Melibea. He has approached her, according to Andreas, as men approach only their mistresses» (75). Her reading of Calisto as a parody of the courtly lover is based on the fact that Andreas Capellanus, in his De Amore, had cautioned against directly addressing a woman to express one's feelings toward her. ${ }^{5}$ But Melibea actually encourages him when he speaks to her about her "perfecta hermosura» (86): "iPor gran premio tienes éste, Calisto?» (87) and even promises him "más ygual galardón» (87) if he perseveres in praising her and expressing his devotion to her. According to María Eugenia Lacarra, in this conversation, Melibea, "consigue, por una parte, que el diálogo prosiga y, por otra, que se desvíe defi nitivamente del cauce cortesano sentimental y se inserte en el sarcasmo cruel» (15). In other words, Melibea knows the language of amor cortés, just as Calisto does, and she, like him, chooses not to follow the rules that go with it. ${ }^{6}$ After this initial encouragement, Melibea turns on her suitor and berates his "loco atrevimiento" and his expressions of "ilícito amor» (87). Upon realizing that Melibea is not actually acceding to his entreaty, Calisto is crushed and, according to Lacarra, shows his ignorance of the true nature of his conversation with Melibea (15). ${ }^{7}$ Lobera et al. observe that, even though Calisto has been thoroughly reprimanded by Melibea, he does not repent of his actions or his words (clxviii).

One line of criticism views this opening scene of Act 1 as a dream of Calisto. Miguel Garci-Gómez first proposed this interpretation of the opening scene in 1985 . He argues that, since it is Melibea who exits this scene, Calisto has in fact never left his bedroom, where we next see him calling out for Sempronio. According to Garci-Gómez: "Calisto acaba de dialogar con ella [Melibea]. Pero ni la hemos visto allí, físicamente, ni hemos visto que saliera. Su presencia se desvaneció. Como se desvanecen las apariciones. Calisto... habrá tenido una aparición, una visión, un sueño» (14). If, from the beginning, Calisto is only dreaming this wonderfully coincidental meeting with Melibea, this would seem to support

5.- On this point see Alan Deyermond's article «The Text-Book Mishandled: Andreas Capellanus and the Opening Scene of La Celestina.»

6.- Lacarra observes, «La exageración de Calisto, por una parte, y la ausencia de cualquier alabanza del carácter virtuoso de Melibea, por otra, así como la falta de promesa de servicios pasados o futuros como era preceptivo, revelan en efecto a Calisto como un mal discípulo de Capellanus» (14). Baltanás contends that Calisto is not a parody of the courtly lover since he never sets out to follow this paradigm (17).

7.- «Melibea flirtea desde el primer instante hasta el momento del rechazo» (Lacarra 15). 
Lida de Malkiel's opinion that Calisto is simply a useless dreamer. ${ }^{8}$ GarciGómez, furthermore, likens Calisto's dream-vision of Melibea to a divine vision, an interpretation that justifies his famous opening line, "En esto veo, Melibea, la grandeza de Dios» (85). ${ }^{9}$ The idea of divine vision resurfaces in Calisto's first conversation with Sempronio when he insists that Melibea is a goddess, not just a mortal woman: "Por dios la creo, por dios la confesso, y no creo que hay otro soberano en el cielo aunque entre nosotros mora» (95). ${ }^{10}$

Alan Deyermond sees the opening scene as a comic reworking of Andreas Capellanus. According to Deyermond, Calisto misuses his textbook on love when he attempts to speak to Melibea. His mishandling of his source material results in failure which makes him appear foolish. Deyermond states: "Calisto's opening speech to Melibea is couched in flamboyant, exaggerated and - as it turns out - in ludicrously unsuccessful terms. Melibea's ambiguous replies lead him on and, until the final and brutal disillusionment cuts him short, he becomes more and more deeply involved in his amatory rhetoric» (218).

When Calisto complains to Sempronio after Melibea initially rejects him, Sempronio points out that he should not despair over Melibea when he could have any woman he wants. He praises Calisto's "hermosura, gracia, grandeza de miembros, fuerça, ligereza» (99) and claims that «a constellación de todos eres amado» (100). According to Baltanás, this observation is particularly telling because Calisto could have other women but he has set his eyes on the most difficult one to obtain. According to Baltanás, "Calisto es cazador, y sabe que podría obtener muchas piezas de aquellas que todo el mundo caza. Pero él aspira a la caza mayor, al trofeo singular: no cualquier mujerzuela fácil, no una hembra cualquiera, sino Melibea» (6).$^{11}$ Lobera et al. seem to concur with this opinion because they observe that "Calisto no deja de tener su lado calculador..." (clxix).

Although Calisto mentions Melibea's noble lineage, grace and virtue, he expends much more rhetoric on describing her physical charms. He waxes poetic about her hair, eyes, eyelashes, eyebrows, nose, mouth, teeth, and lips, shape of her face, breasts, skin, hands, fingers and fingernails ${ }^{12}$

8.- She writes: «Para el soñador egoísta no hay mundo objetivo. Lo que hay es su discurrir sobre sí mismo, su 'dulce ymaginación', que se lanza sin lastre desde el menor trampolín de realidad y anima su elocuencia de sonoras cláusulas» (358).

9.- «Melibea se presenta en escena con el papel de aquellos dioses que, desde los tiempos de Homero, se habían venido apareciendo a los escogidos y dialogaban con ellos...» (GarciGómez 14).

10.- Calisto again uses religiously-infused language, ironically, when he first sees Celestina, naming her, like Christ, «resurrección de mi muerte» (116).

11.- It is obvious that this interpretation of Calisto as «cazador» fits in very nicely with the falcon hunting incident of the first scene of Act I.

12.- See pages 100-101 of Severin's edition. 
However, he prefaces this head-to-toe description, so popular in the sentimental novel, with a revealing statement to Sempronio: «...lo que te dixere será de lo descobierto, que si de lo occulto yo hablarte sopiera, no nos fuera necessario altercar tan miserablemente estas razones» (100). Clearly Calisto's intentions toward Melibea are quite clear. If he had seen, and we assume enjoyed, all the splendors of her body, he would not find himself in such a miserable state of unrequited desire.

Sempronio is clearly aware that Calisto wants a sexual relationship with Melibea. When he promises to help him win Melibea as his own, the servant says, in an aside, "traérgela ha hasta la cama» (103). ${ }^{13}$ When Sempronio brings Celestina to meet with Calisto for the first time, the young nobleman praises the go-between, calling her «reverenda persona» (116). $\mathrm{He}$ extols Celestina's virtue which he sees reflected in the physiognomy of her face: «por la filosomía es conoscida la virtud interior» (116). ${ }^{14}$ Calisto, of course, is again misreading his sources. If physical beauty is a sign of inner virtue, then certainly the detailed description that he had given to Sempronio of Melibea's physical charms would indicate that she is of a most virtuous character. But, as we shall see, she fails to act with modesty, discretion or virginal virtue. The physical description of Celestina offered by Pármeno, that of «una puta vieja alcoholada» (108), does not seem to substantiate Calisto's praise of Celestina's outward beauty as indicator of her virtue.$^{15}$ In fact, her hideous appearance is a true reflection of her inner, malevolent nature. ${ }^{16}$ Ironically, Melibea's beauty conceals hidden passions that are waiting to surface and she will do nothing to restrain them once she has decided to begin an illicit relationship with Calisto. ${ }^{17}$

According to Lacarra, Melibea, from the beginning, "No actúa con la discreción que toda dama debe tener, con la mesura que de tal se espera, no con la modestia a que su condición de doncella le obliga ... debería haber terminado la conversación al darse cuenta de la intenciones de Calisto en lugar de coquetear con preguntas y promesas» (15).

Calisto fails in his first attempt to woo Melibea and is an equally inept master in his own house. His servants make fun of him constantly and he

13.- According to Baltanás, «Ni los criados de Calisto ni la vieja Celestina se engañan acerca de la naturaleza de la pasión que atormenta al joven» (7).

14.- Lacarra points out that Calisto addresses Celestina as if she were «una gran dama, digna intermediaria de la ficción sentimental» (16).

15.- Also, when Lucrecia describes Celestina to Alisa, she points out the prominent scar on her face: «aquella vieja de la cuchillada...» (152).

16.- For an excellent study of the physiognomy of Celestina, see Lillian von der Walde Moheno's article «El cuerpo de Celestina: un estudio sobre fisonomía y personalidad.» Referring to Celestina's overall appearance she states: «La representación física de Celestina debió ser descodificada, por los receptores coetáneos, como la de un ser repulsivo; sus rasgos evidencian el mal y causan asco»...(130).

17.- Lobera et al. state that Melibea «una vez enamorada, no escatimará ni riesgo, ni responsabilidad, ni su cuerpo ni probablemente su alma» (clxxii). 
is made to look ridiculous. For example, still in Act I, Sempronio makes a terrible joke after Calisto claims that Melibea is a goddess. Sempronio says that Calisto is worse than the Sodomites who wanted to have relations with angels, whereas, Calisto wants to make love to a goddess. Calisto, in the midst of his despair and exaggerated praise of Melibea, bursts out laughing. ${ }^{18}$ As Lacarra observes, such behavior is unthinkable in a true courtly lover (16). The fact that Calisto is not able to remain in character as the long-suffering lover, as well as the fact that both he and his servant are clearly aware of his less-than-honorable intentions toward Melibea, reveal much about Calisto's true character or, perhaps, lack thereof. Lacarra emphasizes that, in this conversation between Calisto and Sempronio, the latter treats his master as an equal thus further undermining his posture as noble lover (15-16).

At the beginning of Act II we see Calisto anxious to win, not only the approval and help of Celestina, but also that of his servants. In the first lines of Act II, Calisto asks Pármeno and Sempronio if he had done the right thing by giving Celestina 100 gold pieces to cement their deal. He directs himself to the servants as «hermanos míos (130),» thus erasing any social distinction between them in a way similar to Sempronio's conversation with his master in Act I. Sempronio reassures him that he did well and praises his generosity, saying that by giving to others Calisto increases his own honor. There are a number of ironies inherent in Sempronio's remarks. First, and most obviously, he hopes that Calisto's generosity will spread magnanimously also to him. Second, Sempronio invokes sacred scripture to justify the value of bestowing gifts on others by quoting Acts 20:35 — «It is more blessed to give than to receive. ${ }^{19}$ The idea that this notion of Christian charity is applied to a gift given to a gobetween to obtain the sexual favors of a young woman is comical at best and heretical at worst. Sempronio's opinion that Calisto's honor grows in direct relationship to his beneficence further distorts the picture of a charitable nobleman when we consider to whom, and for what purpose, he has used his riches. Any lingering perception of Calisto as a courtly lover of noble character is clearly being systematically erased. But, as Castells points out, Calisto is more than just a parody of a courtly lover or a transgressor of the ideals of nobility; he suffers from an extreme lack of selfconfidence (209). Lida de Malkiel has clearly pointed out this character

18.- Calisto: ¿¿De qué te ríes?

SEMPronio: Ríome, que no pensava que havía peor invención de peccado que en Sodoma.

CaListo: ¿Cómo?

Sempronio: Porque aquéllos procuraron abbominable uso con los ángeles no conoscidos, y tú con el que confiessas ser Dios.

Calisto: ¡Maldito seas! Que hecho me has reýr, lo que no pensé ogaño (95).

19.- «¡ $\bigcirc$ qué glorioso es el dar! ¡ $\bigcirc$ qué miserable es el recebir!» (130). 
trait as evident in the scenes in which he asks for reconfirmation from his servants: she speaks of «la debilidad con que [Calisto] continuamente está justificándose ante sus criados, ansioso de ganar su aprobación» (357). A lack of self confidence, coupled with sexual desire, help to account for Calisto's irrational behaviors and flights of fantas .

At the beginning of Act III, Sempronio praises his master for the generosity he has shown Celestina and tells him that he should rest, that all is in the good hands of Celestina. But Calisto does assert his authority somewhat when he insists that Sempronio go to Celestina's house to see that she acts quickly on his behalf. Calisto is suffering from lovesickness with all the symptoms espoused by the medicine and literature of the time (Lobera et al. clxix). ${ }^{20}$ His suffering makes him impatient, irritable and obstinate in the treatment of servants as he wallows in his own misery. ${ }^{21}$ In his conversation with Celestina, Sempronio speaks about Calisto's total lack of composure and his lack of confidence in himself and in Celestina: "Este nuestro enfermo no sabe qué pedir; de sus manos no se contenta; no se le cueze el pan. Teme tu negligencia...(138). We also know that Calisto has completely misread Sempronio's motives for his offer to help his master in his love affair. Calisto addresses Sempronio saying «Sabido eres; fiel te siento; por buen criado te tengo...» (131). Sempronio at first refused to run after Celestina, claiming that he feared leaving Calisto alone because, in such a distraught state, his master may die or go crazy if left alone. ${ }^{22}$ In a clever handling of dramatic irony in which we, as readers, know more about Sempronio's true greedy nature than his master appears to, we know that he wants to stay with Calisto simply to avoid going out into the street to chase after Celestina. Sempronio attempts to school Calisto with passages straight from Petrarch's De remedii, to wit, that pursuing unhappiness is akin to lunacy and that he should try to find some enjoyable distraction from pining away for Melibea. ${ }^{23}$ Sempronio's rhetoric, however, does not excuse him from the task of following after Celestina. As soon as Sempronio departs, Calisto again demonstrates his dependence on his servants when he asks Pármeno, "qué te parece de lo que oy ha passado?» (133). Pármeno, not yet ready to cooperate fully in the "plan» to win Melibea, tells his master that his 100 gold coins could have been better spent on gifts for Melibea than on Celestina. He also insists that Celestina is now in control of Calisto's

20.- Melibea, too, exhibits all the classic symptoms of love-sickness in her interview with Celestina in Act $\mathrm{X}$.

21.- Among the adjectives that Lobera et al. use to describe Calisto we find the following: «impaciente, desordenado, contumaz, iracundo, despótico, desatento, derrochador... (clxviii).

22.- Sempronio counsels Calisto: «no dexar trasponer tu pensamiento en aquellos crueles desvíos que recebiste de aquella señora en el primer trance de tus amores» (132).

23.- Essential to the identification of the influence of Petrarch on the Tragicomedia is Alan Deyermond's The Petrarchan Sources of La Celestina. 
fate since his master had made the alcahueta aware of his secret desire. But Calisto responds by saying that he does not dare try to woo Melibea directly after she initially rebuffed him and he asks if Pármeno approves of what he has done. Pármeno does not and tells his master that he risks losing his body and his soul if he continues to deal with Celestina. As we would imagine, this straightforward and honest answer of Pármeno causes Calisto to rage at his servant and, for the second time in this conversation, he attributes Pármeno's attitude to envy. Of course, Pármeno has not expressed any envy of Calisto's love affair but, to Calisto, that is beside the point. He reads the situations and relationships around him as he wills. Fed up with listening to the common-sense arguments of Pármeno, Calisto calls for his horse so that he can ride by the house of his beloved. At this point, as Baltanás observes, «Ni los criados de Calisto ni la vieja Celestina se engañan acera de la naturaleza de la pasión que atormenta al joven. Con crudo lenguaje, lleno de sarcasmo, habla el mismísimo Pármeno al oír relinchar al caballo: '¿Rehincháys, don cavallo? ¿No basta un celoso en casa? ¿O barruntas a Melibea?’» (7). Pármeno is obviously upset when rebuked by his master. He drops the sophisticated arguments and complains that, for all his great show of suffering, Calisto is really just another beast in heat. ${ }^{24}$

The next time we see Calisto is in Act v. Celestina comes to his house to report on her first meeting with Melibea. As we have come to expect, given his impatience, Calisto launches into rhetorical hyperbole on seeing Sempronio and Celestina approaching his door. He worries what news she may bring and laments the time she has kept him waiting. He goes so far as to say that his life depends on what Celestina tells him about Melibea. He tells Pármeno to open the door for «essa honrrada dueña, en cuya lengua está mi vida» (176). On this and other occasions, I agree with Lida de Malkiel when she says that Calisto «se lanza sin lastre desde el menor trampolín de realidad y anima su elocuencia de sonoras cláusulas. Calisto se embriaga oyéndose hablar; sus palabras van creándole la realidad a medida que las derrama en series cada vez más osadas...» (358).

Celestina finally speaks directly with Calisto in Act vi. She addresses him as «mi nuevo amador de la muy hermosa Melibea» (176) and immediately asks him what more he is willing to pay for her services. Calisto can wait no longer to hear the details, telling Celestina to get to the point or "toma esta spada y mátame» (177). In the throes of unrequited desire, Calisto expresses his impatience in rhetorical hyperbole. When Celestina responds that Melibea initially reacted like a raging bull when she spoke to the young woman, Calisto immediately despairs, despite the fact that

24.- In Baltanás's words: «Pármeno 'animaliza' a Calisto, su mal es el mismo que el del caballo que presiente la yegua» (7). 
Celestina tells him that Melibea has agreed to see her again. Lida de Malkiel, in speaking of Calisto's singular lack of patience, notes that «Para su exaltada imaginación es insoportable ajustar la urgencia de su deseo al paso normal del tiempo, y por eso estalla en arranques de impaciencia $\tan$ frecuentes como variadas» (360). Sempronio appears thoroughly disgusted with Calisto's childish petulance: "No ternía este hombre sufrimiento para oýr lo que siempre ha desseado» (178). After drawing out the dramatic tension a bit longer, Celestina tells Calisto that the news is favorable. Calisto claims that his very life depends on the outcome of the alcahueta's meeting with Melibea and this drama-king image begins to wear on both Celestina and the servants. ${ }^{25}$ In an aside, Pármeno comments on Calisto's «liviano y desvariado apetito» (180) which is driving him to disgusting rhetorical excess. Even as Celestina attempts to give him the details of her interview with Melibea, he constantly interrupts her with exuberant exclamations. When Celestina tells Calisto that she told Melibea that he was suffering from a toothache and needed a prayer from her to cure him, Calisto praises her "astucia» and calls her «discreta en mensages» (183) —euphemisms praising Celestina's abilities to lie and deceive. It is important to note, too, that Sempronio and Pármeno are both privy to the conversation between Calisto and Celestina, and Calisto periodically asks his servants' opinions about what they are hearing. Again, we see demonstrated his lack of self-confidence which leads to him giving himself over «inerme a sus servidores» (Lida de Malkiel 356).

Next follows the scene in which Celestina gives Calisto the cordón she had received from Melibea as a token to "cure» Calisto. ${ }^{26}$ Many critics have studied the exuberant reception that Calisto gives to this object. ${ }^{27}$ $\mathrm{He}$ literally worships the girdle, flying into raptures of ecstasy that border on the obscene. Recently, Kevin Larsen investigated Calisto's reaction to Melibea's cordón in terms of fetish theories. Larsen maintains that, although Freud was the first to specifically mention a belt or girdle in a case study on fetishes, he finds Alfred Binet's analysis more helpful for a study of Calisto's fetish behavior with the girdle: «The French psychologist ... discusses at length the relationship between normal love and its

25.- When Celestina and Calisto go to his room to speak at length about her visit to Melibea's house, Pármeno exclaims "qué rodeos busca este loco por huyr de nosotros para poder llorar a su plazer con Celestina de gozo...; por preguntar y responder seys vezes cada cosa sin que esté presente quien la pueda dezir que es prolixo!» (180). It is also worth noting that this passage is one of Rojas's additions to the original Comedia.

26.- Lobera et al. note that the cordón is «símbolo inequívoco de entrega amorosa, y el dolor de muelas designación incluso popular del deseo erótico...» (clxxii).

27.- Among the many articles are: Alan Deyermond, «Hilado-cordón-cadena: Symbolic Equivalence in La Celestina»; Javier Herrero, "The Stubborn Text: Calisto's Toothache and Melibea's Girdle»; Michael Solomon, "Calisto's Ailment: Bitextual Diagnostics and Parody in Celestina»; F.M. Weinberg, "Aspects of Symbolism in La Celestina»; and, Geoffrey West, "The Unseemliness of Calisto's Toothache.» 
exaggeration, which is fetishism. Indeed, he asserts that there is a certain fetishistic content in most attraction; so, what he calls 'grand fétichisme' is in reality a tangent of the normal and healthy. Binet's elaboration of the ties between religious and erotic fetishism is also revealing with regard to Calisto's discourse» (510-11). Calisto calls the cordón "santo" (185) and "mi gloria» (187), while at the same time, erotically questioning the object: "¿O qué secretos avrás visto de aquella excellente ymagen?» (187). Larsen cites Binet's category of fetishism associated with a simple material object as applicable to Calisto's case. According to Binet, the object becomes a fetish when it moves beyond being a simple reminder of the beloved and, instead, becomes an independent object loved for its own sake. As Larsen points out in the scene between Calisto and the cordón, the girdle "takes on a life of its own, in effect, equaling and then replacing her [Melibea] as the object of his diseased affections» (511). Celestina steps in to put a stop to Calisto's fetish behavior, reminding him that the rapture he feels caressing the girdle may replace that for the actual desired object, i.e. Melibea. She admonishes him: «tratar al cordón como cordón por que sepas hazer differencia de habla quando con Melibea te veas; no haga tu lengua yguales la persona y el vestido» (188). Sempronio's objections to Calisto's "play» with the girdle are even more direct: "por holgar con el cordón, no querrás gozar de Melibea» (188). Furthermore, Calisto's behavior is irritating to everyone who witnesses it as Sempronio asserts: "Que mucho hablando matas a ti y a los que te oyen» (188). Celestina's and Sempronio's protests make it clear that Calisto's touching and fondling of the cordón is a fetish substitute for his desire for Melibea's body. Also, this is another example of the servants and Celestina taking command of the scene and admonishing Calisto for his behavior.

In this same scene, when Celestina calls Melibea "gentil (190),» Calisto takes offense that his beloved is described with such a pedestrian adjective. He reprimands the alcahueta by asking her "¿Crió Dios otro mejor cuerpo?» (190). From this question, it is obvious that Calisto has his mind set on her physical attributes rather than her gentility as observed by Celestina. Calisto then enumerates all her physical charms, again much to the chagrin of his servants and Celestina. ${ }^{28}$

Calisto appears next in Act vill when Sempronio and Pármeno overhear him singing. Although the song is not original with Rojas, it is telling that Calisto's song is one that intertwines the idea of imminent death with that of desire:

En gran peligro me veo, en mi muerte no ay tardança,

28.- On this point, Severin remarks: «El escepticismo de los criados ante el éxtasis de Calisto en posesión del cordón de Melibea intensifica la parodia de aquél como amante cortés» (ed. 191). 
pues que me pide el desseo

lo que me niega sperança (218). ${ }^{29}$

Calisto is so distracted that he does not know if it is night or day and must be told by his servants that dawn has come after he has spent a sleepless night pining after Melibea. Upon realizing that morning has come, Calisto sets off for the church of La Magdalena to pray for Celestina's success in winning Melibea for him: "yré a la Madalena; rogaré a Dios aderece a Celestina y ponga en coraçón a Melibea mi remedio...» (219). On Calisto's ironic choice of a church dedicated to Mary Magdalene, David Burton asserts that "Calisto clearly misuses and misappropriates religion by going to church to pray that a virtuous woman should fall into sin. This misappropriation of faith and prayer is made all the more evident when the church he chooses is one dedicated to and bearing the name of Mary Magdalene, the patron of repentant sinners and fallen women» (38). Calisto's motives for prayer are clearly inappropriate. In desperation, he wants to cover all his bases, not relying solely on Celestina's powers of persuasion but also asking God to intervene to satisfy his desires. Sempronio counsels his master to have more patience and tells him that it is unreasonable to assume that he can quickly win Melibea's favors "como si ovieras embiado por otra qualquiera mercaduría a la plaça» (220). Again, truth is in the mouths of the servants. Calisto does, in fact, believe that he can «buy» Melibea by paying Celestina to work on his behalf. And he sees Melibea as a "mercaduría," just like any other bauble that might catch his fancy in the market place. But Calisto insists on praying in the church of the Magdalene, asserting that he will remain there until the servants come to him with good news from Celestina. Rojas's audience would surely have seen Calisto's pious zeal as not only misdirected, but blatantly ridiculous and even heretical.

In Act IX, after Celestina's successful interview with Melibea, the gobetween catches up with Sempronio and Pármeno who have come to persuade their master to leave the church. They warn Calisto not to reveal his suffering in a public place and remind him «Por Dios, que huygas de ser traýdo en lenguas, que al muy devoto llaman ypócrita» (249). It is noteworthy, as Burton points out, that Celestina refuses to give Calisto the news about Melibea inside the church and wants to establish some distance from it before speaking with him: «Salgamos, señor, de la yglesia, y de aquí a la casa te contaré algo con que te alegres de verdad» (249). Burton claims that Celestina wants to keep the sacred and the pro-

29.- The song is by Diego de Quiñones, Cancionero General, 288 (Severin , ed. 218). According to Lobera et al. the song «debió de ser bastante famosa en los últimos años del siglo $\mathrm{XV}$ (aparece citada y glosada en varias fuentes) y primeros del siglo XVI (de cuando datan las primeras versiones completas conservadas: en el Cancionero general y el de García de Resende)» (195). 
fane separate. He states that "Celestina respects the sanctity of the sacred space by not speaking of her impious mission inside the building» (39). While this is true, Celestina's statement also implies that she is anxious to return to Calisto's house where, after receiving the favorable news about Melibea, Calisto will have access to the payment she anticipates. When Celestina tells him that Melibea is won over, Calisto initially reacts with incredulousness, telling her that the servants will think she is mad to have uttered such a statement. Sempronio takes control of the situation and whispers in his master's ear that Celestina needs to be immediately and handsomely rewarded for her work. He reproves both his master's lack of self-confidence and prolixity: «Con tu desconfiança, señor, con tu poco preciarte, con tenerte en poco, hablas essas cosas con que atajas su razón. A todo el mundo turbas diciendo desconciertos... Dale algo por su trabajo; harás mejor, que esso esperan essas palabras» (250). At this prompting, Calisto decides to give Celestina a gold chain rather than the cloak she had previously asked for. As we know, this is the valuable gift that will lead to her death. Pármeno murmurs behind his master's back about the value of the chain and the fact that Celestina will certainly not share it with them. ${ }^{30}$ Pármeno also comments that Calisto appears to be in a trance, hanging on Celestina's every word: «está colgado de la boca de la vieja, sordo y mudo y ciego, hecho personaje sin son...» (250). This characterization of Calisto, as utterly beguiled by Celestina, is indicative of his single-minded obsession with Melibea and his complete dependence on the alcahueta. When Celestina finally tells Calisto that Melibea returns his love, he does not trust his own senses to perceive her meaning but calls on Sempronio and Pármeno to verify her words. Specifically he says that he is not sure if he is dreaming or if he is awake. Garci-Gómez comments that Calisto lives in a world of dreams and fantasies and that «no podia confiar en la realidad de lo que veía o lo que oía, por mucho que lo intentara» (19). This evaluation concurs completely with Pármeno's assessment of his master as deaf, dumb and blind. Even when Celestina announces that she has arranged for Calisto and Melibea to speak that evening at midnight, Calisto remains incredulous: "ital cosa espero? ¿Tal cosa es possible aver de passer por mí?» (251). When Sempronio and Pármeno question the sudden acquiescence of Melibea to the desires of Calisto, Calisto turns on the very servants he had just relied on to help him navigate this new reality. He berates them calling them "locos, vellacos, sospechosos» (253). When Celestina takes her leave, Calisto crumbles to the ground in a state of exhaustion due to the sleepless nights he has endured waiting for Celestina to bring him news of Melibea.

30.- Pármeno is aghast when Calisto calls the valuable chain «una cadenilla»: "¿Cadenilla la llama?... No estima el gasto. Pues yo te certifico no diesse mi parte por medio marco de oro, por mal que la vieja la reparta» (250). 
Act XII opens with Calisto, who is restless, afraid that he has overslept and will be late to his appointed rendezvous at midnight. Once again, he is irritable and impatient with his servants. Larson comments on Calisto's behavior in this scene (and others) as indicative of his "never-ending adolescence» (513). When Calisto, together with Sempronio and Pármeno, arrives at Melibea's house, Calisto insists that Pármeno approach the door to see if Melibea is waiting for him. Pármeno excuses himself saying that it would upset Melibea to realize that other people were privy to the couples' meeting. Again, it is the servant who must remind the master that secrecy is of the upmost importance. When Pármeno speaks to Sempronio, he complains that Calisto had wanted him to be the first to approach so that Pármeno would run all the risk if, in fact, the meeting was a trap. When Lucrecia is the first to answer his call, Calisto overreacts. Rather than asking after her mistress he immediately assumes that he has been tricked. This complete lack of faith in Melibea is another example of his lack of self-confidence as well as a lack of confidence in Celestina, in whom he had placed all his hope and not a little of his wealth. When Melibea speaks to Calisto he is, of course, overcome with joy only to have that joy dashed when Melibea informs him that she has agreed to speak with him only to dissuade him from pursuing her further. His reaction is to curse his servants, curse Celestina and, first and foremost, bemoan his torment. Melibea reassures him that she only wanted to be certain of his resolve and, once again, the reaction of Calisto is swift and extreme. He speaks of his unworthiness in comparison with Melibea's perfection. His self-doubt quickly returns: «me estoy remirando si soy yo Calisto a quien tanto bien se [le] haze» (261). Melibea curses the doors that keep them apart to which the impetuous Calisto replies that he will break them down. It is Melibea who must remind him, "No sueltes las riendas a la voluntad» (262). However, as we have seen, Calisto's voluntad, his single-minded desire for Melibea, is his only drive, unrestrained by warnings from his servants or the pleadings of his beloved. He only desists when Melibea invites him to scale the walls of her garden on the following night so that they may be together. Calisto, as Burton has noted, attributes his success with Melibea to the prayers he had offered at the Church of the Magdalene. Burton states that "Once again Calisto misuses and misunderstands the role of religion ... In reality, counter to Calisto's beliefs, God and the saints are not responsible for bringing him to Melibea's door. Calisto has succeeded through Celestina's aid, through her manipulation of Melibea, and through Melibea's own free will» (39-40). ${ }^{31}$ Calisto is equally mistaken about the bravery of Sempronio and Pármeno

31.- On this point Lida de Malkiel asserts that for Calisto «Dios es, sencillamente, un instrumento de mayor potencia, no de distinto orden, que los sirvientes o la alcahueta, y la equívoca elucubración teológica que, presa de la obsesión amorosa, confunde las categorías sagradas y profanas.» (369). 
when he reassures Melibea that he has come accompanied by the bravest of men. All the while, the servants have been planning the speediest and surest route for a quick escape, should their master be detected.

Upon returning home after this first meeting with Melibea, Calisto again seeks the reassurance and affirmation of the servants. He wants to know if the servants had overheard his conversation with Melibea. ${ }^{32}$ When he asks Sempronio and Pármeno if they had been afraid while waiting on him, the two servants lie about their cowardice and assure their master that they were ready to defend him with the lives. Calisto is either gullible enough to believe them or suffers from complete selfdelusion. He even offers the two further rewards for their fine work. ${ }^{33}$ As we know, Sempronio and Pármeno will have no further interaction with Calisto. Soon they will be arrested and executed for the murder of Celestina which they perpetrate shortly after leaving their master to rest after the night spent in conversation with Melibea.

In Act XIII, we witness the many and conflicting reactions of Calisto to the news of the execution of Sempronio and Pármeno. He, at first, bemoans their deaths, calling them "mis leales criados» (278), "mis grandes servidores» (278), and "mis fieles secretarios y consejeros» (280). But then, quickly, his lament turns inward and he expresses concern for his honor: "O amenguado Calisto, deshonrrado quedas para toda la vida» (280). Calisto repeats his fear of loss of honor at least three more times ${ }^{34}$ before he changes his tune and vows not to let the servants' deaths stand in the way of his affair with Melibea. He now calls Sempronio and Pármeno "sobrados y esforçados» (281) and states that "agora o en otro tiempo de pagar havían» (281). As a short-term measure to save face, Calisto decides to pretend that he was out of town the previous day. He even says that he will pretend to be insane, if necessary, so that he can keep his rendezvous with Melibea. Guardiola-Griffiths sees Calisto's decision as cowardly and indicative of his complete failure to play the part of the "amo" when his servants are executed. She states: "Calisto es consciente de su deber, pero prefiere dedicarse a la consecución de goces mayores» $(43)^{35}$

32.- Perhaps a foreshadowing of his desire in the garden to have «testigos de su gloria» (285).

33.- Severin points out the humorous possibilities of Sempronio's and Pármeno's cowardice in this act: "First they voice their fears, then they run away gratuitously; next they try to impress one another with their past feats of courage; finally they try to impress Calisto with their bravery" (Tragicomedy and Novelistic Discourse 78).

34.- «yo bien siento mi honrra» (280); « $\bigcirc$ mi triste nombre y fama, cómo andas al tablero de boca en boca!» (280); "anda mi hazienda de mano en mano y mi nombre de lengua en lengua» (281).

35.- On this point, Lobera et al. observe that «después de la ejecución de Sempronio y Pármeno, en un extraordinario monólogo, se plantea afrontar el hecho, asumir de algún modo sus responsabilidades como señor. Al final su impulso — que no llegado a plan- naufraga en un mar de dudas y acaba anegado por su obsesivo deseo sexual, por los fantasmas que 
In Act XIV, Calisto scales Melibea's garden walls for the first time. In this encounter, Calisto is anxious to have a physical relationship but he must overcome Melibea's initial rebuffs. Not surprisingly, Calisto's primary concern is with his own feelings and desires: "Mora en mi persona tanta turbación de plazer...» (284); "nadando por este huego de tu desseo toda mi vida» (285); "no esté queda mi pasión; para penar de nuevo» (285). And then the coup de grâce - when Melibea agrees to succumb to Calisto desires, he reproves Melibea's dismissal of her maid, saying that he would welcome Lucrecia as one of the "testigos de mi gloria» (285). His desire to have witnesses for his conquest flies in the face of any concern for keeping the affair a secret. John England, among others, ${ }^{36}$ has written about Calisto's shocking statement to Lucrecia. In his article, "Testigos de mi gloria': Calisto's Bestial Behavior,» England writes: «In wishing to take Melibea's virginity in the presence of a witness, Calisto seeks to lower himself and Melibea to the level of the beasts; the behavior which he proposes was condemned vigorously by theologians and secular writers alike, as there was general agreement that sexual activity both inside and outside marriage should be conducted in private» (81). England ties this act of potential voyeurism to other instances in the work. For example, in Act VII, when Celestina wants to watch Pármeno in bed with Areúsa, or when Lucrecia seeks to usurp Melibea's place and embraces Calisto in Act XIX. Also relevant here are the comments of the servants Sosia and Tristán. While not ocular witnesses to the love-making, since they are down below in the street waiting on their master, they overhear the lovers' conversation and comment of Calisto's good fortune. ${ }^{37}$ As England points out, the comments of Sosia and Tristán «provide a powerful commentary on Calisto's callous indifference to the recent deaths of Pármeno and Sempronio" (88). Sosia openly comments on Calisto's attitude towards the death of his former servants: «dos moços entraron en la salsa destos amores» (286). To which Tristán replies: «Ya los tiene olvidados... Veslos a ellos [a Melibea y Calisto] alegres y abraçados, y sus servidores con harta mengua degollados» (286).

Calisto is notably laconic when Melibea laments the loss of her virginity. His only comment is that he is surprised to find it is already morning and leaves without another word to Melibea. On this point, Baltanás states, "Calisto, post coitum, ya no vuelve a hablar. Abrevado su deseo, no parece que tenga humor para decir más nada. Ni una palabra tierna,

pueblan su imaginación, pero es difícil no creer que esos fantasmas acuden precisamente a su invocación» (clxx).

36.- On Calisto's bestial behavior, see also Severin's Witchcraft in Celestina; and Deyermond's "El que quiere comer el ave': Melibea como artículo de consumo.» Guardiola-Griffiths clearly states that «El deseo que siente Calisto le transforma en una especie de bestia, que ya no razona sino que actúa según sus instintos amorosos» (44).

37. - «Oygo tanto que juzgo a mi amo por el más bienaventurado hombre que nasció...» (285). 
ni un requiebro amoroso. Ni siquiera una dulce despedida» (11). When Calisto finds himself alone later, shut up in his room, he bemoans his loss of honor due to the public executions of Sempronio and Pármeno but barely speaks about Melibea. He merely states that, now that his lust has been satisfied ${ }^{38}$ he is keenly aware of the public infamy he must suffer. And, of course, Calisto places the blame for his troubles squarely on the shoulders of another-in this case, the judge who condemned his servants to death. Specificall , Calisto says "O cruel juez, y qué mal pago me as dado del pan que de mi padre comiste. Yo pensava que pudiera con tu favor matar mil hombres sin temor de castigo» (289). In studying this section of the Tragicomedia, Rank comments that "Calisto's words consistently hint at the potential for corrupt ties between the judge and what was obviously an influential family» (157). ${ }^{39}$ Calisto goes on to call the judge a "público delinquente» (289). But, true to his mercurial nature, Calisto soon changes his tune completely and says that the judge had acted swiftly and decisively in his decision to execute the servants in order to preserve his (Calisto's) honor — «él por no hazer bullicio, por no me disfamar, por no sperar a que la gente se levantasse y oyessen el pregón, del qual gran infamia se me siguía, los mandó justiciar tan de mañana» (291). It is evident that Calisto has changed his mind because he now calls the judge a "verdadero hermano» (291). And, just to cheer himself up completely, Calisto finally reminds himself of the recent "gran gozo» (291) he had enjoyed with Melibea and affirms that «ningún dolor ygualará con el recebido plazer» (291). He renounces all concern for honor, riches and family and decides to close himself off in his room by day and spend his evenings in the paradise of Melibea's garden. As Dunn has noted, "Reversing day and night, unaware of either time or necessity, [Calisto] is removed from the world's natural pulse and rhythm. He can respond to nothing but the flux of feeling and the allurements of fantasy» (113). Calisto endures the hours until he can once again be with Melibea by turning to his «dulce ymaginación» (292). Addressing his imagination, as if it represents a partner in conversation, Calisto implores: «trae a mi fantasía la presencia angélica de aquella ymagen luzinente; buelve a mis oýdos el suave son de sus palabras...» (292). While Calisto carries on this lengthy soliloquy, Sosia and Tristán discuss their master's mental state. Sosia is surprised that Calisto remains shut up in his room all day. But Tristán astutely observes that their master is suffering from conflicting emotions: "aquéxale por una parte la tristeza de aquellos moços, por otra le alegra el muy gran plazer de lo que con su Melibea ha alcançado» (293).

38.- «agora que está elada la sangre que ayer hervía» (288).

39.- Rank speculates that this judge may, at one time, have lived in Calisto's home: «He calls the judge among other things 'hombre de baxo suelo'... who has repaid so badly his father's hospitality in whose house he may have lived, indicated by the phrase: 'del pan que de mi padre comiste'...» (161). 
Tristán is perhaps being a bit too generous in labeling Calisto's reaction to the deaths of Sempronio and Pármeno as sadness. Calisto is actually more concerned about the public knowledge of their involvement in his love affair than in expressing grief for their deaths. Nonetheless, it is true that Calisto is dealing with a number of warring emotions simultaneously, as Tristán observes.

Calisto does not appear again until Act XIX when he has another rendezvous with Melibea in her garden. He overhears Melibea and Lucrecia singing and waits to make his presence known so that he can listen to them. ${ }^{40}$ The lovers address each other as "mi señora y mi bien todo» and «mi señor y mi alma» respectively (322). Unexpectedly, it is Lucrecia who throws herself into Calisto's arms before Melibea embraces him. Melibea upbraids her maid who she thinks has gone mad with passion («loca de plazer») and tells her, "déxame gozar lo que es mío; no me ocupes mi plazer» (323). Severin concludes that Lucrecia's amorous overtures to Calisto are a reaction to the sensuality of this scene (323). On Lucrecia's actions, England states, "It is little wonder that by Act XIX she [Lucrecia] seeks to live a little herself by removing Calisto's armour with enthusiasm, provoking an order from Melibea to keep her hands off» (85-86). ${ }^{41}$ When Calisto turns his attentions to Melibea she implores him to restrain himself and complains of his "riguroso trato» (323). England sees a sharp contrast between Calisto's words and actions when he is apart from Melibea and his comportment when they are together- «his fine words when thinking about Melibea when they are apart are replaced by coarse and aggressive speech and behavior in her presence» (88). Guardiola-Griffiths concurs, stating that Calisto's language when he is with Melibea «dista mucho de los servicios, sacrificios, devoción y obras pías que primero tenía ofrecidos» (43). But we must recall that these promises of service and sacrifice on Calisto's part have been mere verbiage. In fact, the only real act of devotion Calisto offers to Melibea is his own suffering. When she asks him to stop manhandling her garments, Calisto responds with the infamous line, "Señora, el que quiere comer el ave, quita primero las plumas» (324). Guardiola-Griffiths contrasts the delicate words and courtly language of Melibea during this encounter with what she calls «la actitud más grosera de Calisto» (43). Commenting on Calisto's coarse comment, this critic states "Cualquier intento de mantener su cortés habla ha desaparecido con estas palabras tan explícitas» (43). Larsen feels that, in this scene, Calisto's "carnal behavior and gross

40.- Burke analyzes this song in terms of the sense of sound. In the song, Lucrecia also refers to the senses of sight, smell and taste. He finds significant the fact that the women's song does not mention touch, traditionally considered the basest of the five senses (111-12).

41.- Lobera et al. agree with this explanation, stating that «Se supone que Lucrecia aprovecha para manosear a Calisto en razón de que, como criada, debe ayudarle a despojarse de su armadura» (321). 
speech figure more as a compensation for other inadequacies he scarcely senses» (510) and later states that "[h] is forwardness may be a screen for its opposite» (510). Larsen questions Calisto's capacity for any genuine deep sentiment. Such an interpretation certainly adds a level of depth to what most critics see as Calisto's coarseness and indifference to Melibea's physical and emotional well-being. ${ }^{42}$

Melibea's answer to Calisto's crude metaphor is to ask if he would like Lucrecia to bring them something to eat and drink: «Señor mío, ¿quieres que mande a Lucrecia traer alguna collación?» (324). We may interpret Melibea's question as either a stalling tactic in response to Calisto's rough treatment or she may simply want to indulge in other sensual pleasures, such as food or drink, to accompany the upcoming sexual pleasures. Burke, however, rejects the idea that this scene is an example of a medieval feast involving indulgence of all the senses and claims that in Act XIX «ingestion ... is metaphorical and not real» (116). While it is true that Calisto rejects Melibea's offer of refreshments — «No ay otra colación para

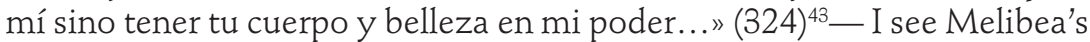
offer as part of her complete surrender to the joys of the flesh. She has, by her own account, spent a month enjoying sexual encounters with Calisto and it is not surprising that her awakening to erotic pleasure should incite her other senses as well.

The next time Calisto speaks is at dawn when he realizes he must leave Melibea's garden. As we have seen, Calisto was very laconic after their first sexual encounter and, here, he speaks of "la noble conversación de tus delicados miembros» (324). In other words, Calisto is praising his own physical interactions (exchanges?) he had enjoyed with Melibea's body rather than any real conversation between the two. Also, given the former explicitness of Calisto's language, it is not too farfetched to say that the phrase «delicados miembros» specifically refers to Melibea's genitals and breasts. Obviously, Melibea has likewise enjoyed sexual pleasure as she responds that she is the one who actually reaps the greater joy from their encounters. ${ }^{44}$

The next words that Calisto utters are in response to the agitated shouts of his servants, Sosia and Tristán, waiting below. The scene is ironic because, as Lida de Malkiel observes, this is one of only two in-

42.- I am aware that such a phrase is projecting contemporary ideas on the couple's relationship but I feel that Calisto's refusal to engage in any meaningful conversation with her beyond a litany of his own desires is indicative of callousness and lack of self-perception. As Lida de Malkiel observes, "Calisto se embriaga oyéndose hablar; sus palabras van creándole la realidad a medida que las derrama en series cada vez más osadas» (358).

43.- Lida de Malkiel points out that this is not the only time that Calisto refuses food when it is offered. He rejects food also in Acts VIII, XI, XII, XIII, and XIV (358).

44.- Melibea states: «Señor, yo soy la que gozo, yo la que gano; tú, señor, el que me hazes con tu visitación incomparable merced» (324). 
stances when Calisto shows true bravery and acts out of concern for another. But this second time it will bring about his death. ${ }^{45}$ It is also ironic because the servants respond to Calisto's offer of help by telling him that they do not need his assistance because the noise that disturbed them was only Traso and his ruffians making a ruckus. Calisto also refuses to heed Melibea's pleas for him not to descend without his armor. Impulsive to the end but, in this last instance, magnanimous at best and foolish at worst, he falls from the ladder in his haste to assist his servants. Calisto's last words mirror those of the dying Celestina when he cries out "¡O váleme Santa María, muerto soy! ¡Confessión!» (326).46

We return to the questions we asked about Calisto at the beginning of this essay. Arguments for him as a parody of a courtly lover, an eternal adolescent, a sexual predator or a pure egotist may, at times in the narrative, be entirely applicable. But if we look at the totality of his actions and, more importantly, his words (since these are the only vehicle for understanding characters in a work without authorial narration), we do discover complexities. Calisto often displays a lack of confidence in himself and in others. He is self-absorbed to the point of distraction and regularly experiences bouts of depression, sleeplessness and self-imposed solitude. While love-sickness accounts for his mood swings, when his erotic desires are fulfilled, he shows himself to be unrefined and course in his treatment of Melibea. He loses himself in his own rhetoric but he constantly turns to his servants for advice and affirmation. Calisto does not trust his own senses nor his own perceptions of events around him. Pursuing his obsession with Melibea, he loses sight of larger questions such as class standing, honor and his responsibilities as señor of his household. But Calisto's lust is not that of an unrestrained adolescent since he sets his sights on a sole individual of noble lineage. And he shows himself forthright and generous in his interactions with Celestina. Calisto depends on his servants for advice, which he most often ignores, and his loyalty towards those who serve him waxes and wanes in direct proportion to his success with Melibea. Calisto is difficult to decipher, as Rank has pointed out, but at the core of his personality is an eternal conflict between the sexual desires of the individual and the moral dictates of a society. Baltanás clearly sees this conflict, as played out in the Tragicomedia, as very much a product of its time, i.e., the end of the medieval period and the beginnings of the Renaissance in Spain. He states that the Tragicomedia reflects «Un conflicto de amor y sexo en una época - albores del Renacimiento- que se estaba replanteando ambos conceptos así como

45.- The first is when, during his meeting to speak to Melibea through the closed door, he hears noises inside the house but vows to remain at his post regardless of the consequences: «Bullicio oygo, perdido soy! Pues biva o muera, que no he de yr de aquí» (259).

46.- We recall Celestina's cry in Act XII: «iAy, que me ha muerto, ay, ay, confessión, confessión!» (274). 
las relaciones entre los mismos, sin encontrar aún una salida» (17). This irresolvable conflict is what puts the tragedy in Rojas's Tragicomedia and what constitutes the tragic in the characterization of Calisto. But there is also an element of the comic in the depiction of Calisto's personality. At times, Calisto is a besotted buffoon in his pursuit of Melibea. He misreads the motives of those around him and he floats in a world with his own erotic desires as the center of his universe. His rhetoric is overthe-top and tries the patience of his servants and Celestina - characters whose practical nature stands in sharp contrast to the fantasy world of Calisto. He has an uncanny ability to justify his actions and rationalize his decisions. Even Calisto's death is ironic since, in one of his few moments of noble action, he suffers an accident. His pedestrian death - falling from a ladder and splattering his brains on the pavement- sets in motion the inevitable suicide of Melibea and the lament of her father. Calisto's words and deeds, as we have noted, embody both the comic and the tragic. If we follow Calisto's trajectory throughout the Tragicomedia, we discover the cruel consequences of blind obsession while also laughing at the fool in love. Calisto is, as Baltanás astutely observes, a product of the historical moment of his creation but, in other respects, he is timeless. His sexual desires take over his personality, obscuring a complete understanding of him. But what we do see and hear from Calisto creates a figure with whom we can, at times, sympathize and, at other times, disdain. 


\section{Works Cited}

BattanÁs, Enrique. "El matrimonio imposible de Calisto y Melibea (notas a un enigma).» Lemir 5 (2001): 1-17. Web. 21 Feb. 2009.

Burke, James F. Vision, the Gaze, and the Function of the Senses in Celestina. University Park, Penn.: Pennsylvania State UP, 2000. Print. Penn State Studies in Romance Literatures.

BurTon, David. «Fallen, Unrepentant, and Unforgiven: Calisto at la Madalena.» Celestinesca 27 (2003): 35-41. Print.

Castells, Ricardo. "Calisto and the Imputed Parody of Courtly Love in Celestina.» Journal of Hispanic Philology 15.3 (1991): 209-20. Print.

- Fernando de Rojas and the Renaissance Vision: Phantasm, Melancholy, and Didacticism in Celestina.» University Park, Penn.: Pennsylvania State UP, 2000. Print. Penn State Studies in Romance Literatures.

Deyermond, Alan. "Divisiones socio-económicas, nexus sexuales: la sociedad de Celestina.» Celestinesca 8.2 (1984): 3-10. Print.

-. "Hilado-cordón-cadena: Symbolic Equivalence in La Celestina.» Celestinesca 1.1 (1977): 6-12. Print.

- The Petrarchan Sources of "La Celestina.» Oxford: Oxford UP, 1961. Print. Oxford Modern Languages and Literatures Monographs.

-. "El que quiere comer el ave': Melibea como artículo de consumo.» Estudios románicos dedicados al prof. Andrés Soria Ortega en el XXV aniversario de la Cátedra de Literaturas Románicas. 3 vols. Granada: U of Granada, 1985. I: 291-300. Print.

-. "The Text-Book Mishandled: Andreas Capellanus and the Opening Scene of La Celestina.» Neophilologus 45 (1961): 218-21. Print.

Dunn, Peter N. Fernando de Rojas. Boston: Twayne, 1975. Print. Twayne's World Authors Series, 368.

ENGLAND, John. "Testigos de mi gloria': Calisto’s Beastial Behavior.» La corónica 28.2 (2000): 81-90. Print.

Garci-Gómez, Miguel. «El sueño de Calisto.» Celestinesca 9.1 (1985): 11 22. Print.

Guardiola-Griffiths, Cristina. "Calisto y las consecuencias del deseo. Una posible influencia de las Metamorphosis en la Tragicomedia.» Celestinesca 28 (2004): 33-46. Print.

Herrero, Javier. "The Stubborn Text: Calisto's Toothache and Melibea's Girdle.» Literature Among Discourses: The Spanish Golden Age. Eds. Wlad Godzich and Nicholas Spadaccini. Minneapolis: U of Minnesota P, 1986. 132-47. Print.

LACARRA, María Eugenia. "La parodia de la ficción sentimental en 'La Celestina'.» Celestinesca 13.1 (1989): 11-29. Print. 
LARSen, Kevin S. "Calisto on the Couch: An Aspect of Fernando de Rojas's 'Modern' Psychological Insight.» Neuphilologische Mitteilungen 101.4 (2000): 505-17. Print.

Lida de Malkiel, María Rosa. La originalidad artística de La Celestina. Buenos Aires: Editorial Universitaria de Buenos Aires, 1962. Print.

MarTin, June Hall. Love's Fools: Aucassin, Troilus, Calisto and the Parody of the Courtly Lover. London: Tamesis, 1972. Print. Colección Tamesis, Serie A, Monografías, 21.

Rank, Jerry R. "'O cruel juez, y que mal pago me has dado...': Or Calisto's Urban Network.» Fernando de Rojas and Celestina: Approaching the Fifth Century. Proceedings of An International Conference in Commemoration of the 450 th Anniversary of the Death of Fernando de Rojas. Purdue University, West Lafayette, Indiana, 21-24 November 1991. Eds. Ivy A. Corfis and Joseph T. Snow. Madison, WI: Hispanic Seminary of Medieval Studies, 1993. 155-64. Print

RojAs, Fernando de. La Celestina. Ed. Dorothy S. Severin. 3rd ed. Madrid: Cátedra, 1989. Print. Letras hispánicas 4.

RojAS, Fernando de y "Antiguo Autor.» La Celestina: Tragicomedia de Calisto y Melibea. Eds. Franciso J. Lobera et al. Barcelona: Crítica, 2000. Print. Biblioteca clásica, volume 20.

Severin, Dorothy Sherman. Tragicomedy and Novelistic Discourse in Celestina. Cambridge: Cambridge UP, 1989. Print. Cambridge Iberian and Latin American Studies.

- Witchcraft in Celestina. London: Dept. of Hispanic Studies, Queen Mary and Westfield College, 1995. Print

Solomon, Michael. «Calisto's Ailment: Bitextual Diagnostics and Parody in Celestina.» Revista de estudios hispánicos 23 (1989): 41-64. Print.

WALDE Moheno, Lillian von der. «El cuerpo de Celestina: un estudio sobre fisonomía y personalidad.» eHumanista 9 (2007): 129-42. Web. 22 Feb. 2009.

WeinberG, F.M: "Aspects of Symbolism in La Celestina.» Modern Language Notes 8 (1971): 136-53. Print.

WeST, Geoffrey. "The Unseemliness of Calisto's Toothache.» Celestinesca 2.1 (1979): 3-10. Print.

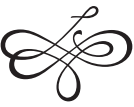





\section{Scarborough, Connie L., "The Tragic/Comic Calisto: Obsessed and Insecure», Celestinesca, 34 (2010), pp. 179-200.}

\section{RESUMEN}

En las páginas de la Tragicomedia de Calisto y Melibea, Calisto se revela como un personaje más complejo que aparece inicialmente. En vez de ser un simple estereotipo del amante cortesano, manifiesta unas contradicciones e inconsistencias que revelan una falta de seguridad en sí mismo. Mientras persigue ciegamente su pasión sexual por Melibea, no logra dirigir bien su casa y busca la aprobación y la ayuda de sus criados y de Celestina. Incluso falla como amante sufrido porque constantemente muestra impaciencia e irritabilidad hacia los a su alrededor. Calisto es el rey de la retórica excesiva y muestra una falta de confianza en Celestina a pesar de que le recompensa con generosidad. Emplea mal las creencias religiosas por rezar para que gane a Melibea y malinterpreta los motivos y el carácter de sus criados. Cuando logra poseer físicamente a Melibea, la trata con severidad y el lenguaje grosero que utiliza cuando está con ella contrasta con su discurso cortés cuando no está en presencia de la dama. Calisto es tanto trágico como cómico y nosotros, los lectores de la Tragicomedia, presencian las consecuencias crueles de una obsesión ciega mientras que también nos reímos del necio enamorado.

PAlabras Clave: Celestina, Calisto, trágico, cómico, parodia, adolescente, contradicciones, obsesión

\section{ABSTRACT}

Calisto emerges from the pages of the Tragicomedia de Calisto y Melibea as a more complex character than he initially appears. Rather than a mere stereotype of the courtly lover the contradictions and inconsistencies he manifests reveal his own insecurities. While blindly pursuing his sexual passion for Melibea he fails to manage well his own household and constantly seeks the approval and help of his servants and Celestina. He even fails as the long-suffering lover when he continuously shows himself to be impatient and irritable to all around him. Calisto is the king of rhetorical excess and but shows a single lack of confidence in Celestina even though he handsomely rewards. He misuses religious belief by praying for Melibea's affections and completely misreads the motivations and character of his servants. When he does possess Melibea physically, he treats her harshly and his rhetoric is crude in contrast to his courtly speeches he offers when not in her presence. Calisto is both a tragic and comic figure and readers of the Tragicomedia witness the cruel consequences of blind obsession while also laughing at the fool in love.

KEY WORDS: Celestina, Calisto, tragic, comic, parody, adolescent, contradictions, obsession. 